紹 介

日臨麻会誌 Vol.41 No.2, $166 \sim 170,2021$

\title{
腹臥位手術時の気管チューブの事故拢管を防ぐ チューブ固定法のエ夫
}

赤石 敏* 古川 宗* 久志本成樹*

[要旨] 術中の気管チューブ事故抜管は危険な術中合併症の一つであるが，さらにそれが腹臥位で 起きた場合には致命的となる可能性がある. それを防止するために当科で 10 年以上前から行って きた, 腹臥位手術時の気管チューブの固定法である ear-hooking 法を紹介する.

キーワード : 腹臥位, 気管チューブ事故抜管, ear-hooking 法

\section{はじめに}

高度救命救急センターに搬送される多発外傷患者 で，頝椎・上部胸椎損傷を合併している場合，その 多くがJackson tableでの 3 点ピン固定下に腹臥位 での頝椎・胸椎後方 (除圧) 固定術を施行される。そ の際，もしも術中に腹臥位での事故抜管が発生した 場合，速やかな仰臥位への体位変換は非常に困難で ある ${ }^{1)}$. 腹臥位でのマスク換気下に迅速に仰臥位に 戻して再挿管するか, Jackson tableの患者の下に 潜って気管支鏡，エアウエイスコープ，あるいは McGRATH MACビデオ喉頭鏡を使用して腹臥位 のまま迅速に再挿管するしかない2)。いずれにせよ， 心停止や低酸素脳症発生の危険性を伴う緊急事態と なる ${ }^{3)}$.

3 点ピン固定はface mask式など他の腹臥位での 頭部固定法とは異なり, 重力方向に「宙吊り」の状 態で引つ張られる。また顔面の皮脂や汗によるテー プの剥離や，腹臥位での唾液流出によるテープの剥 $\begin{array}{llr}\text { 受付日 } & 2020 . & 8.26 . \\ \text { 受理日 (採択日) } & 2020 . & 11.24 .\end{array}$
離が起こる可能性があり，通常のテープ固定法では 術中に突然挿管チューブが事故抜管となる危険性を 否定できない．頭部に全周性にテープを回す固定法 もあるが，頝椎後方固定術ではテープが術野や消毒 野にかかってしまい，また固定時も頝部を前屈させ る必要があり危険なので推奨されない.

著者らの施設では 10 年以上前から，腹卧位での 事故抜管の危険性を下げることができると考えられ る ear-hooking法(図 1)を考案し，腹臥位手術症例 200例以上で安全に施行してきた。

今回，その固定テープの作成方法と固定方法を紹 介する。

\section{Ear-hooking 法の手順}

1. 手術患者入室前に挿管チューブ固定テープを作 成する。手術室にある幅 $5 \mathrm{~cm}$ のハイラテックス テープ(イワッキ社)や3Mテープ(Health Care 社)を用意し，これを術前訪問で目視にて症例の 顔面の広い狭いを決定し，それに合わせて $23 〜$ 

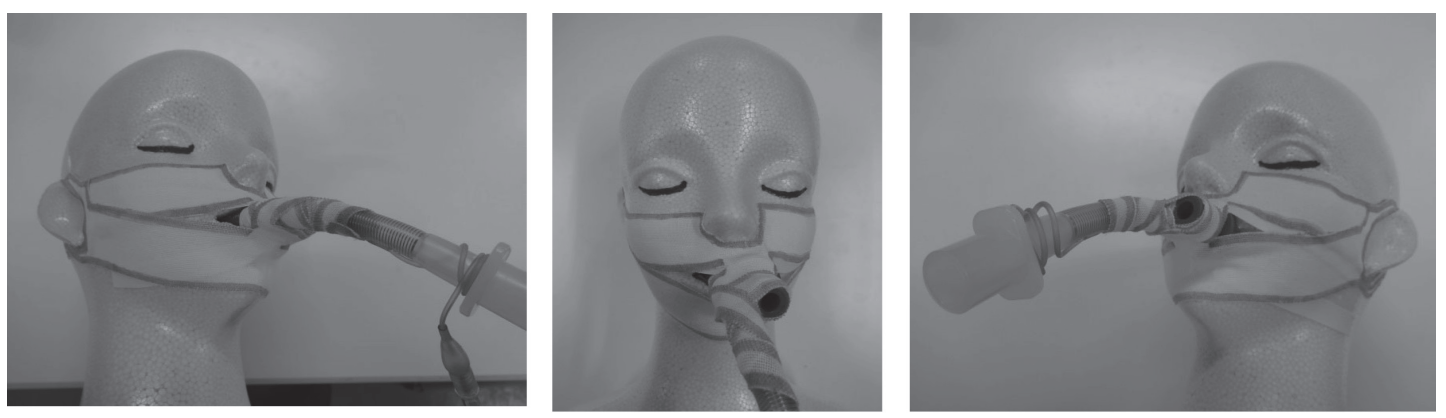

〜判りやすいように辺縁を蛍光マーカーで着色している〜

図1 Ear-hooking methodの外観

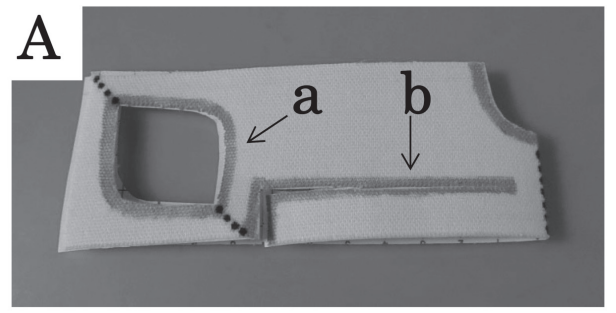

両耳介フックを作成(a)後、半分に折って 巻き付け部分を上下 2 枚ごとカットする(b)

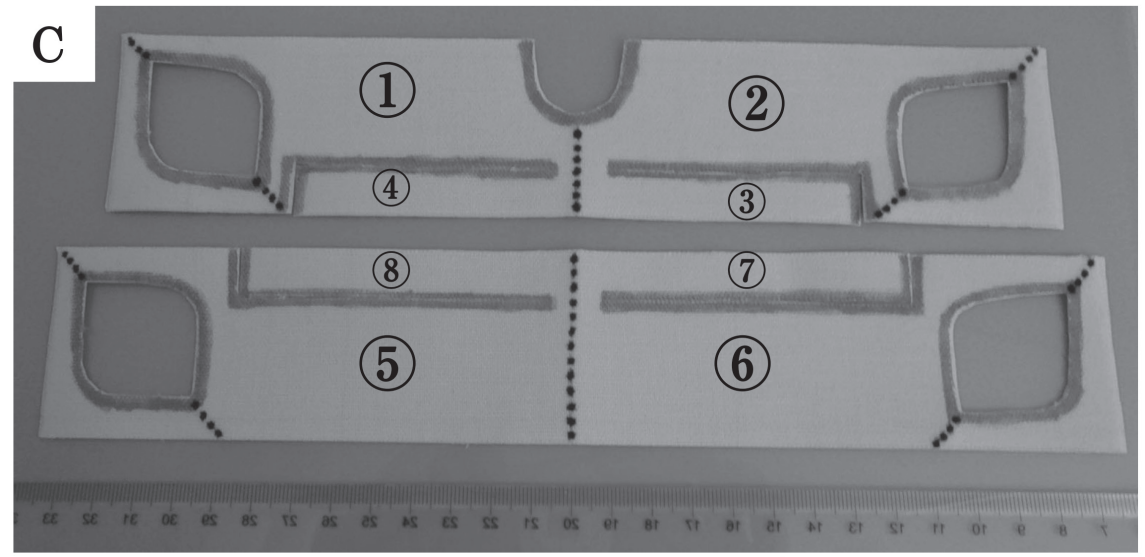

上顎用はテープの下縁に、下顎用はテープの上縁に巻き付け部分を作成する

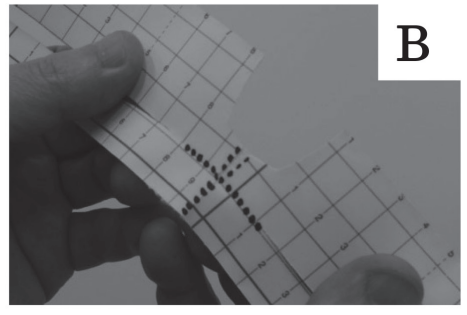

裏紙を引っぱりながら十字に 4 分割

図2 固定テープの切り方

$27 \mathrm{~cm}$ に2本カットする(図2)。下顈固定用のも のは上顎用より $1 \sim 2 \mathrm{~cm}$ 長めにカットしておく. 両端を三角形に折ってその内側を円弧状にカッ トし，耳介にかけるhookを作成する(図2A-a).

2. テープの中央を折って, hookの近くから約 $1 \mathrm{~cm}$ の幅でチューブ固定用の切り込み部分を作成す
るが，折った中央部の約 5 ～10mm 手前でカッ 卜を止めておく(図2A-b)。チューブ固定用の切 り込みは，上顎用はテープの下縁に，下顎用は テープの上緑に作成し，さらに上顎用は上緑に 鼻翼用の切り込みを入れておく(図 $2 \mathrm{C}) .2$ 枚の テープは哀紙を引っ張って, 十字に四分割して 


\section{※上顎固定}
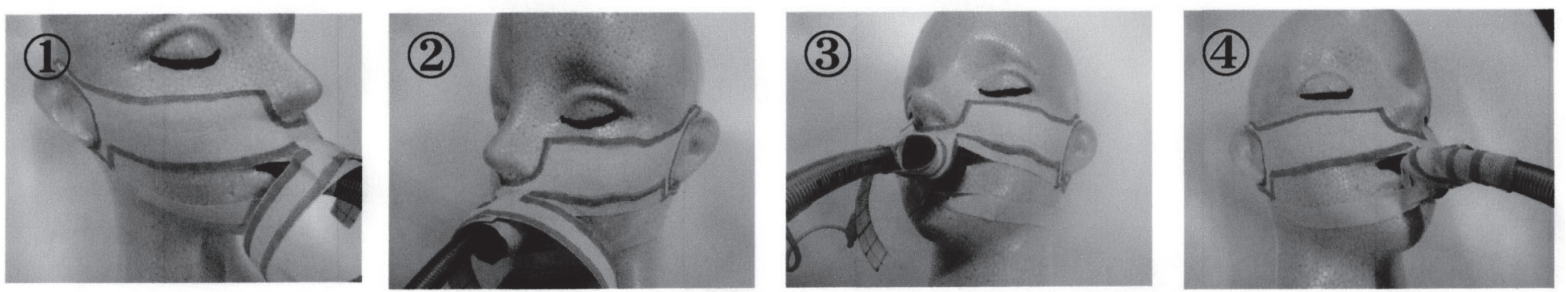

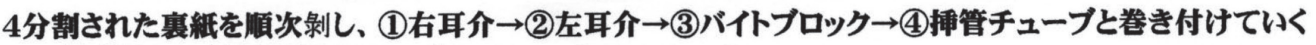

\section{※下顎固定}
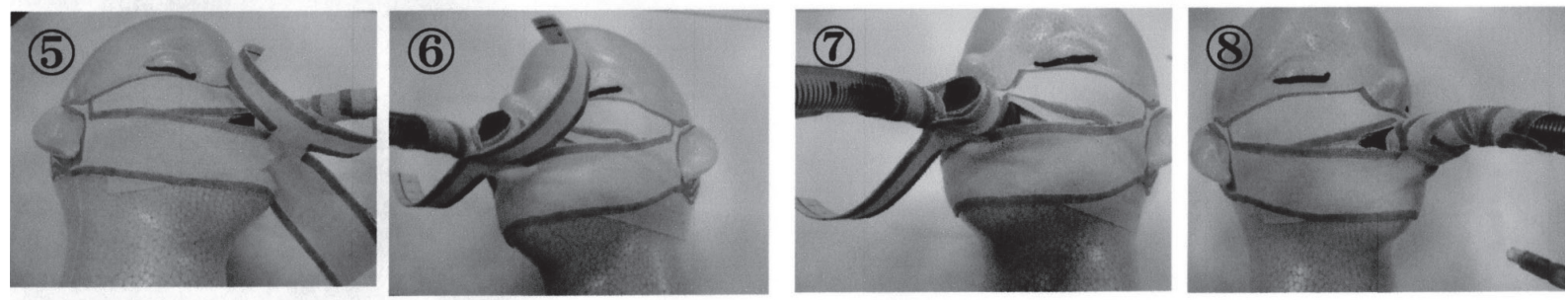

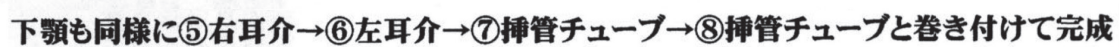

図3 テープ固定法

おくと固定が容易になる(図2B).

3. 仰臥位で插管したのち通常の $1.2 \mathrm{~cm}$ 幅のテープ で1巻き固定しておき，作成した固定用テープ の四分割した裏紙を順次剥がしながら，上顎固 定用テープ(図3-(1)(2)(3)(4))から下顎固定用テー プ(図 3- (5)6(7)(8)へと順次，挿管チューブに巻 き付けていく.

4. 3 点ピンを頭部に刺入し腹臥位に固定した後に, 気管チューブに 1 〜 本接続した延長の蛇管を 円弧状に側方に誘導する(図4)。写真からわか るようにチューブは宙吊りでテーブルにはまっ たく接していない点が, face mask法などの他 の腹臥位での固定法とは異なる。逆に言えば, 気管チューブがテーブルに接して折れることが ないので，顔面への固定が確実ならばspiral tubeである必要はないことになる。

5. 手術終了後に仰臥位に戻してから，覚醒前に ear-hookを外し，そのままか，あるいは必要最
小限の固定を残してカットしておき，あとは通 常のように抜管する。

\section{II 考 察}

この固定法のポイントは，それぞれの症例に合わ せて適度な張度で固定することであり，特に張度が 緩すぎると事故抜管やバルーンの位置変動の危険性 がある，逆に固定テープが短くてつっぱると earhookが外机る危険性が出てくる。もし張度が適切 でないと感じたらすぐに作り直せばよく，慣れれば 1 分程度で作り直せる.

この ear-hooking 法を初めて行う前には，まずテ ープの切り方を何度も練習しておく必要がある。 あ る程度慣れたら，側臥位あるいはface mask法での 腹臥位手術症例で試行してテープの張度の調整を体 験しておき，その上で本番の 3 点ピン固定での腹臥 位手術の実施を行うのが望ましい.

腹臥位手術で使用される spiral tube は以前から, 


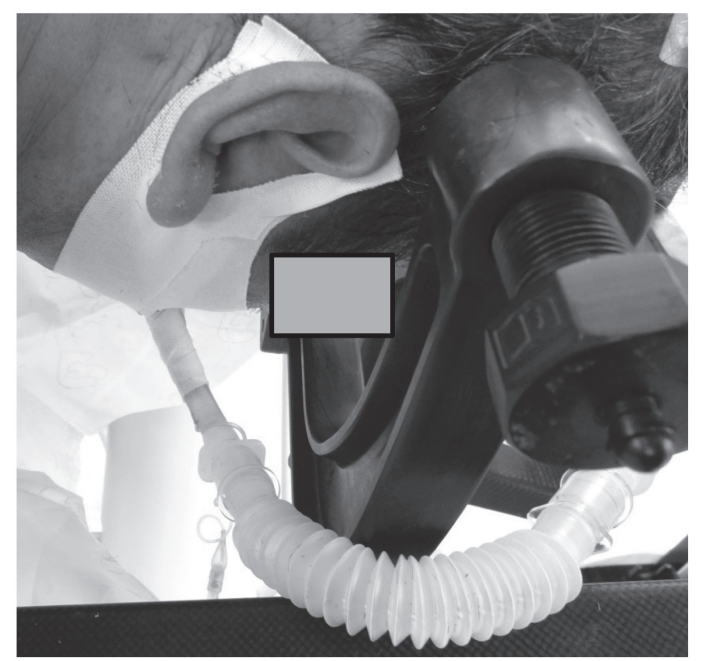

3 点ピンで腹臥位に固定後に、蛇管を円弧状に側方の構造物の 上に誘導して不必要な重力がチューブにかからないようにする

図4腹臥位でのチューブの誘導法

テープの粘着性が悪いことを指摘する意見がある。 腹臥位に伴い垂れてきた唾液などの体液で濡れてし まうことで粘着性はさらに低下すると考えられる。 そのため粘着性がそれほど高くないテープでバイト ブロックのレベルだけを数回巻くだけでは，腹臥位 における事故抜管のリスクは常に存在する。

今回紹介した ear-hooking 法で用いるハイラテッ

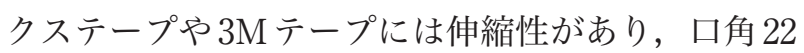
〜 23cm で固定する場合でも挿管チューブの外端近 くまでツ夕状に 3〜4周テープが巻かれるため，皮 脂・汗・唾液や副鼻腔炎からの膿汁流出などで固定 テープが污れても事故抜管するリスクを低下させる ことができる。

通常の幅 $1.2 \mathrm{~cm}$ の固定テープの皮膚面への固定面 積が図2Cの(7) 8) × なのに対し, ear-hooking 法で は図2Cの(1)(2)(6)であり，計算上はほぼ2.5倍か ら 3 倍となり，気管チューブへの巻き付け面積では ほぼ4〜5倍に増加し，粘着力が格段に増大する. さらには ear-hookによる物理的な固定力が加わる ため，たとえ予期せ女外力で気管チューブが引つ張 られたとしても，ear-hookさえ外机なければ事故
抜管に至る危険性は極めて低いと思われる。

注意すべき点として，たとえ本法を実践しても事 故抜管のリスクが完全になくなるわけではなく，や はり術中の注意深いモニター管理や，こまめに気管 チューブが抜けてきていないかを目視で確認するこ との重要性に変わりはない.

\section{最後に}

腹臥位での気管チューブの事故抜管は危険度の高 い術中合併症であり，発生するリスクを可能な限り 下げる必要がある。Jackson tableを用いた腹臥位 では，唾液などが固定部に垂れてくる上に抜管方向 に重力がかかる，腹臥位での事故抜管を防止するた めに今回紹介した ear-hooking method は比較的容 易に実践可能であり，術中死亡をきたしうるこの合 併症を有意に減らすことができるものと考えられ る。

\section{参考文献}

1) De Cosmo G, Congedo E : Unintentional tracheal extubation during prone position : What is the best rescue air- 
way device ? J Emerg Trauma Shock $10: 2-3,2017$

2) Thiel D, Houten J, Wecksell M : Accidental tracheal extubation of a patient in the prone position. A A Case Rep 2 : 20-22, 2014
3) Oliveira VM, Piekala DM, Deponti GN, et al. : Safe prone checklist : construction and implementation of a tool for performing the prone maneuver. Rev Bras Ter Intensiva 29 : 131-141, 2017

\title{
Ear-hooking Method for the Fixation of an Intubation Tube to Avoid Intraoperative Accidental Extubation
}

\author{
Satoshi AKAISHI, Hajime FURUKAWA, Shigeki KUSHIMOTO \\ Department of Emergency Medicine, Tohoku University Graduate School of Medicine
}

Intraoperative accidental extubation of the endotracheal tube during surgery, especially in the prone position, is one of the most critical perioperative complications. In this report, we introduce the "ear-hooking method" of the endotracheal tube to avoid accidental extubation during surgery. We have used this method for more than 10 years in approximately 200 patients with multiple injuries who required posterior cervical supine surgery. For the ear-hooking method, two crafted elastic adhesive tapes fix the intubation tube to the head; one to the upper jaw and the other to the lower jaw. By correctly performing this tube-fixation method, we reduced the risk of fatal intraoperative accidental extubation.

Key Words : Prone position, Accidental extubation, Ear-hooking method

The Journal of Japan Society for Clinical Anesthesia Vol.41 No.2, 2021 